San Jose State University

SJSU ScholarWorks

Master's Projects

Master's Theses and Graduate Research

8-1-2009

\title{
Self Perceptions of Clinical Performance of Accelerated First Degree and Accelerated Second-Degree Graduates
}

Neelam N. Murthi

San Jose State University

Follow this and additional works at: https://scholarworks.sjsu.edu/etd_projects

Part of the Other Nursing Commons

\section{Recommended Citation}

Murthi, Neelam N., "Self Perceptions of Clinical Performance of Accelerated First Degree and Accelerated Second-Degree Graduates" (2009). Master's Projects. 796.

DOI: https://doi.org/10.31979/etd.qgtg-5tk5

https://scholarworks.sjsu.edu/etd_projects/796

This Master's Project is brought to you for free and open access by the Master's Theses and Graduate Research at SJSU ScholarWorks. It has been accepted for inclusion in Master's Projects by an authorized administrator of SJSU ScholarWorks. For more information, please contact scholarworks@sjsu.edu. 


\section{SAN JOSE STATE UNIVERSITY \\ SCHOOL OF NURSING}

\section{MASTER'S PROGRAM PROJECT OPTION (PLAN B) PROJECT SIGNATURE FORM}

STUDENT NAME: Neelam N. Murthi

SEMESTER ENROLLED: Spring 2008

TITLE OF PROJECT: Self-Perceptions of Clinical Performance of Accelerated First and Second Degree Graduates

NAME OF JOURNAL: International Joumal of Nursing education Scholarship

The project and manuscript have been successfully completed and meet the standards of the School of Nursing at San Jose State University. The project demonstrates the application of professional knowledge, clinical expertise, and scholarty thinking. An abstract of the project and two copies of the manuscript are attached.

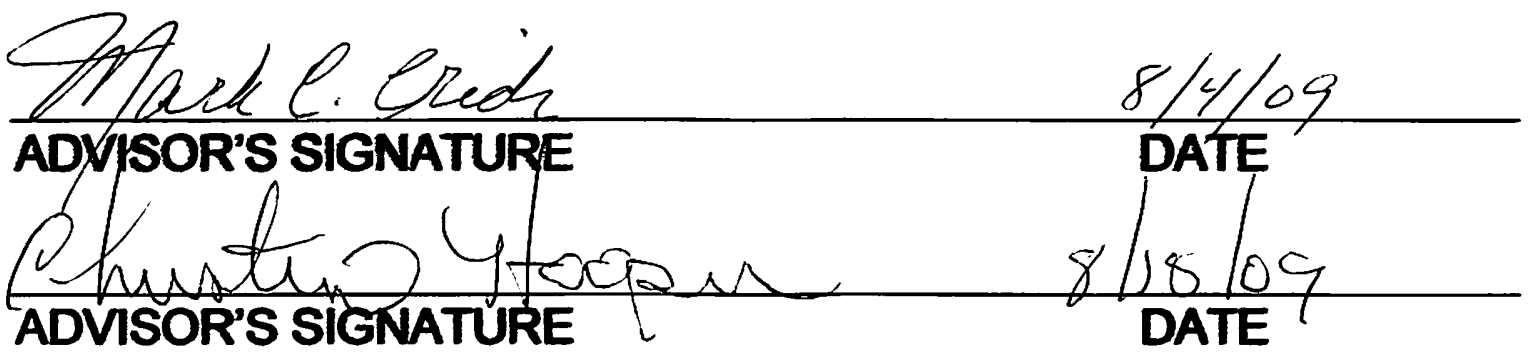

Please submit this form to the Graduate Coordinator. Attach abstract, two copies of the manuscript, and documentation of submission to the journal (i.e., Postal receipt) 


\title{
Self Perceptions of Clinical Performance of Accelerated First Degree and Accelerated Second-Degree Graduates
}

\author{
Neelam N. Murthi BSN, RN, Mark C. Crider PhD, RN, Christine Hooper EdD, RN
}

\begin{abstract}
Currently in the United States, motivated by nursing shortages, numerous ways have been created to recruit nurses in nursing schools. Accelerated nursing programs are increasing rapidly. Colleges and Schools of Nursing around the nation are accepting students seeking their first degree, as well as those with a second degree. This study compared perceptions of clinical performance of accelerated first-degree and accelerated second-degree bachelor of nursing graduates. The intention was to identify whether, after graduation, the two groups held different self-perceptions of performance in the clinical environment. This was to determine if one group has better self-perception of performance than the other to explore how these differences can impact accelerated nursing programs and clinical performance after graduation. The results showed no significant differences in the perception of performance between the two groups; concluding degree status has little or no impact on perception of clinical practice and prediction of practice success from an accelerated program.

Keywords: nursing shortage, clinical performance, new graduate, accelerated nursing graduates
\end{abstract}




\title{
SAN JOSE STATE UNIVERSITY SCHOOL OF NURSING
}

\author{
Neelam N. Murthi \\ Mark C. Crider \\ Chris Hooper
}

Self-Perceptions of Clinical Performance of Accelerated First and Second Degree

Graduates 
The manuscript entitled Self-Perceptions of clinical performance of accelerated first and second degree graduates, or a similar version of it is not under consideration by another journal, nor has it been accepted or published elsewhere. This research based manuscript was approved by the institutional ethics review board.

This study contributes data on the status of accelerated graduates, which could be used in the future research of accelerated nursing programs. The data provides critical information that could be used for evaluating the clinical performance of future first degree and second degree accelerated nursing graduates. 


\begin{abstract}
Currently in the United States, motivated by nursing shortages, numerous ways have been created to recruit nurses in nursing schools. Accelerated nursing programs are increasing rapidly. Colleges and Schools of Nursing around the nation are accepting students seeking their first degree, as well as those with a second degree. This study compared perceptions of clinical performance of accelerated first-degree and accelerated second-degree bachelor of nursing graduates. The intention was to identify whether, after graduation, the two groups held different self-perceptions of performance in the clinical environment. This was to determine if one group has better self-perception of performance than the other to explore how these differences can impact accelerated nursing programs and clinical performance after graduation. The results showed no significant differences in the perception of performance between the two groups; concluding degree status has little or no impact on perception of clinical practice and prediction of practice success from an accelerated program.

Keywords: nursing shortage, clinical performance, new graduate, accelerated nursing graduates
\end{abstract}


In 1971 the first accelerated nursing program was introduced at the Saint Louis University School of Nursing, and by 2008 there were approximately 218 accelerated baccalaureate nursing programs with 26 in the planning stages (American Association of Colleges of Nursing, 2009). Accelerated nursing programs have become popular as they provide the full academic nursing program in a shortened period of time, allowing individuals to complete their nursing education and enter the practice setting more quickly than traditional nursing educational programs. Such acceleration into nursing practice is hoped to contribute to decreasing the nursing shortage.

By 2020, the Health Resources and Service Administration (HRSA, 2006) predicts the nursing shortage will increase to more than one million in the United States (U.S.). The Bureau of Labor Statistics (2008) reports that registered nursing will have the greatest job growth of all U.S. professions through the year 2016. Due to this increasing demand for nurses, many accelerated programs have been created to meet the health care needs of the nation. Accelerated nursing programs produce nurses at a rapid rate to meet the demands of the consumer and the economy. Accelerated nursing graduates assist in decreasing the nursing shortage through rapidly completing the education needed to enter the workforce. Today's nurses need to be able to communicate effectively, think, organize, solve problems, and prioritize according to patients' needs. They need to be able to 
learn and act quickly to keep up with the daily changes in the clinical environment.

With such needs for success in clinical nursing practice this study was interested in examining if there were any differences between self-perception of performance of accelerated first degree and accelerated second-degree graduates, and if so, how might these differences impact accelerated nursing education programs and clinical performance after graduation? By beginning to examine these questions accelerated nursing programs and graduates can better meet our national health care needs.

Because of nursing shortages, fluctuating economy, new technology, and advances in patient care, changes in the nursing education model have occurred, creating new terms and definitions. An accelerated program is defined as a bachelor of science in nursing (BSN) program, which can be completed in 12-18 months, not including pre-requisites. Accelerated second degree students refer to students who have a previous bachelor's degree or a higher degree in a field other than nursing (AACN, 2009). Accelerated first-degree nursing students refer to students who have completed the pre-requisites for a nursing program, but do not hold any other bachelor's degree. 


\section{Research Problem}

The purpose of this study was to identify self-perceptions in clinical performance of recent accelerated first and second-degree graduates from a bachelor of nursing program. Nursing performance has been defined as behaviors that coincide with nursing practice, which include leadership and critical thinking, as well as technical, behavioral, and communication skills (Schwirian, 1978).

The accelerated first-degree students were compared with the accelerated second-degree students to identify whether the two groups held different selfperceptions of performance in a clinical setting. This was to explore the possibility that academic and clinical performance may be enhanced in different ways depending on the academic preparation of the nursing student. There has been little research to evaluate the clinical performance in the work environment comparing accelerated first and second-degree graduates. It is important to know if these groups are performing differently in the clinical environment after graduation in order to determine if nursing programs need to examine their admissions criteria for accelerated students.

\section{Literature Review}

Most of the research that has been conducted in this area to date has compared accelerated students to traditional nursing students (Penprase \& 
Koczara, 2009). The National Council Licensure Examination-Registered Nurse (NCLEX-RN) pass rates, academic performance, program evaluation, and perceptions of preparedness for a nursing career post graduation are some areas examined previously (Seldomridge \& Dibartolo, 2004, Korvick et al, 2008, Raines \& Sipes, 2007, Raines, 2007). Research has suggested that accelerated nursing graduates are exceptional academically with high grade point averages and high pass rates on the board exam (McDonald, 1995, Seldomridge \& DiBartolo, 2004).

Raines \& Sipes (2007) evaluated a second-degree accelerated program and also looked at the reflections of accelerated second-degree students one year after graduation. The reflections from graduates helped to evaluate the students' perception of their preparation for the work environment. This study was a program evaluation of an accelerated program to assess if the program met the needs to produce safe and competent nurses. The results of Raines' study provided evidence that accelerated second-degree programs are effective in preparing nurses for the work environment.

Brewer et al. (2009) studied the demographics of traditional and second degree baccalaureate graduates work characteristics, attitudes toward work, and future career plans. Since most second-degree students are older and more mature, they had more family-work conflict while in the nursing program, and while teamwork comprises a large portion of nursing practice, some accelerated 
graduates demonstrated lower group cohesion. Since socialization into nursing is a large part of the profession, it is important for educators as well as employers to recognize this factor in order to teach and promote group activities. The goal is to decrease the nursing shortage including retaining nurses in the profession. Lack of support at the workplace from peers can cause nurses to leave their current work site, or abandon the nursing profession completely. Accelerated programs assist in decreasing the high demand for nurses by fulfilling the labor market's needs.

Many nurses have been found to work outside of the profession due to burnout and stressful environments (Black, 2008). The costs of hiring and training new nurses in hospitals is tremendous and therefore hiring and retaining nurses are key concepts in hospital budgets. The American Organization of Nurse Executives (AONE, 2009) estimated that the cost of turnover for one Registered Nurse (RN) could be as high as $\$ 50,000$. This amount was calculated factoring in both hidden and visible costs. Hidden costs can include the time leading up to leaving, vacant positions, and loss of efficiency of the new hires during their hiring period due to lack of mentors. Visible costs can include training, recruitment, hiring, and orientation. These costs can vary widely based on the hospital and the specialty areas. Although turnover rates are high and costly, accelerated graduates show an enthusiasm and bring with them a motivated attitude (Raines, 2007). Therefore, satisfaction with performance in the clinical setting is important in order to retain these nurses. 
A recent study (Berkow et al, 2009) assessed the performance of new graduates in the clinical setting. Nurse leaders were surveyed to evaluate new graduate performance. Questions included six areas of competencies; clinical knowledge, technical skills, critical thinking, communication, professionalism, and management of responsibilities. With a sample size of five thousand and seven hundred nurse leaders, results showed that only $25 \%$ of the nurse leaders were satisfied with the performance of the new graduates. Nurse leaders felt graduates were not prepared with clinical and non-clinical skills. Suggestions included the need for hospitals to provide more opportunities for students during clinical rotations. This suggests that schools of nursing and hospitals may need to work together in order for graduates to be more prepared after graduation to perform more successfully as a registered nurse.

From the literature we have a better understanding of the unique educational and practice needs of accelerated students and graduates. This study attempted to examine if qualifications of previous degree attainment may also contribute to the unique needs of these students and graduates.

\section{Methodology}

A non-experimental descriptive study was used for this research. The participants included a sample of graduates from one accelerated BSN program 
who had been working in a clinical setting after graduation. After approval from the University's Institutional Review board, a letter was mailed to all recent accelerated graduates explaining who the researcher was and the purpose of the research. The contact information of the accelerated graduates was obtained from the school of nursing accelerated program project manager at the university. The completed questionnaires were returned to the researcher excluding any identifying information to assure anonymity. Returned responses incorporated the participants' consent. A separate page included basic demographic information such as age, gender, year of graduation, first degree or second degree, area of nursing specialty, and months in current workplace. The instrument included questions regarding the students' perception of performance in the work environment and their behaviors in response to daily nursing practice. The instrument measured the levels of nursing performance indicated by the six dimension scale of nursing performance created by Patricia Schwirian (1978). The six dimension scale includes 52 questions regarding nursing performance. The 52 items are scattered in the instrument and eventually divided into six subscales which are leadership, critical care, teaching/ collaboration, planning/evaluation, interpersonal relations/communication, and professional development. The graduates were asked to state how often they performed these nursing behaviors (frequency) and how well they perform the behaviors in their current position (quality). 
The validity of the six dimension scale was created by an expert panel of nurse leaders, administrators, and educators after a pilot testing of the scale. A factor analysis was conducted with new graduates and supervisors prior to the launch of the final instrument. The original scale was used for self-appraisals of performance, employer appraisals of performance, or perceived adequacy of nursing school preparation for performance (Schwirian, 1978).

Sixty-two questionnaires were sent to recent graduates of a local urban California State University. Eight graduates had a change of address and two had left the program before it began. Excluding these, there were 44 first degree and 18 second degree students remaining. The final sample included 12 first degree graduates and eight second-degree graduates from the accelerated nursing program with a return rate of $27 \%$ and $44 \%$ respectively.

\section{Data Analysis}

After receiving the questionnaires, data was entered onto a spreadsheet by a statistician using the Statistical Package for the Social Sciences (SPSS 16.0). This study examined the self-perceptions of performance in a clinical setting using the behaviors from the six dimension scale of nursing performance. The instrument contained two columns for answers (See Table 1). Column A shows how often the nurse performed the activities in their current position (frequency), 
and column B displayed how well the nurse performs this activity (quality).

Column A describes the frequency of the clinical activity using 1) not expected in this job, 2) never or seldom, 3) occasionally, 4) frequently. Column B of the questionnaire asks the participant the quality of how well they perform the activity in their current job setting using the answers 1) not very well, 2) satisfactorily, 3) well, 4) very well. These activities were divided into subscales of leadership, (five questions), critical care (seven questions), teaching/collaboration (eleven questions), planning/evaluation (seven questions), interpersonal relations/communication (twelve questions), and finally, professional development (ten questions). The results from the questions were then set in the subscale based on the areas of nursing skills (See Table 2). The answers to the subscales were further analyzed using t-tests to see the areas of performance in which graduates are at ease or having difficulty. 
(Table 1) Six Dimension Scale of Nursing Performance (52 questions)

\begin{tabular}{|c|c|}
\hline Column A & Column B \\
\hline $\begin{array}{c}\text { How often do you perform these activities in } \\
\text { your current job? }\end{array}$ & $\begin{array}{c}\text { How well do you perform these activities in } \\
\text { your current job? }\end{array}$ \\
\hline 1- Not expected in this job & 1- Not very well \\
\hline 2- Never or seldom & 2- Satisfactorily \\
\hline 3- Occasionally & 3- Well \\
\hline 4- Frequently & 4- Very well \\
\hline
\end{tabular}

\begin{tabular}{|l|l|}
\hline 1. Teach a patient's family members about the patients needs Column A & Column B \\
\hline 2. Coordinate the plan of nursing care with the medical plan of care & \\
\hline 3. Give praise and recognition for achievement to those under your direction. & \\
\hline 51. Demonstrate knowledge in the ethics of nursing & \\
\hline 52. Accept and use constructive criticism & \\
\hline
\end{tabular}

Schwirian, P.M. (1978). Evaluating the performance of nurses: A multi-dimensional approach. Nursing Research, 27 347-351. 
(Table 2) Six Dimension Subscale Scale of Performance by Patricia Schiwirian (1978)

\begin{tabular}{|c|c|c|}
\hline Scale & Item Number & Item Content \\
\hline LEADERSHIP & $\begin{array}{l}3 \\
23 \\
25 \\
26 \\
41\end{array}$ & $\begin{array}{l}\text { Give praise and recognition for achievement to those under your direction } \\
\text { Delegate responsibility for care based on assessment of priorities of nursing care needs } \\
\text { and the abilities and limitations of available health care personnel } \\
\text { Guide other health team members in planning for nursing care } \\
\text { Accept responsibility for the level of care provided by those under your direction } \\
\text { Remain open to the suggestions of those under your direction and use them when } \\
\text { appropriate }\end{array}$ \\
\hline CRITICAL CARE & $\begin{array}{l}11 \\
18 \\
19 \\
27 \\
30 \\
37 \\
40\end{array}$ & $\begin{array}{l}\text { Perform technical procedures: ex: oral suctioning tracheostomy care, intravenous } \\
\text { therapy, catheter care, dressing changes } \\
\text { Use mechanical devices: ex: suction machine, Gomco, cardiac monitor, respirator } \\
\text { Give emotional support to family of dying patient } \\
\text { Perform appropriate measure in emergency situations } \\
\text { Perform nursing care required by critically ill patients } \\
\text { Recognize and meet the needs of a dying patient } \\
\text { Function calmly and competently in emergency situations }\end{array}$ \\
\hline TEACHING/COLLABORATION & $\begin{array}{l}1 \\
4 \\
5 \\
12 \\
14 \\
28 \\
29 \\
31 \\
32\end{array}$ & $\begin{array}{l}\text { Teach a patient's family members about the patients needs } \\
\text { Teach preventative health measure to patients and their families } \\
\text { Identify and use community resources in developing a plan of care for a patient and hi: } \\
\text { family } \\
\text { Adapt teaching methods and materials to the understanding of the particular audience: } \\
\text { ex: age, educational background, sensory deprivations } \\
\text { Develop innovative methods and materials for teaching patients } \\
\text { Promote the use of interdisciplinary resource persons } \\
\text { Use teaching aids and resource materials in teaching patients and their families } \\
\text { Encourage the family to participate in the care of the patient } \\
\text { Identify and use resources within your healthcare agency in developing a plan of care } \\
\text { for a } \\
\text { patient and his family } \\
\text { Communicate facts, ideas, professional opinions in writing to patients and their familit } \\
\text { Plan for the integration of patient needs with family needs }\end{array}$ \\
\hline
\end{tabular}




\begin{tabular}{|c|c|c|}
\hline Scale & Item Number & Item Content \\
\hline $\begin{array}{l}\text { PLANNING/ } \\
\text { EVALUATION }\end{array}$ & $\begin{array}{l}2 \\
6 \\
7 \\
9 \\
10 \\
13 \\
36\end{array}$ & $\begin{array}{l}\text { Coordinate the plan of nursing care with the medical plan of care } \\
\text { Identify and include in nursing care plans anticipated changes in a patient's conditions } \\
\text { Evaluate results of nursing care } \\
\text { Develop a plan of nursing care for a patient } \\
\text { Initiate planning and evaluation of nursing care with others } \\
\text { Identify and include immediate patient needs in the plan of nursing care } \\
\text { Contribute to the plan of nursing care for the patient }\end{array}$ \\
\hline $\begin{array}{l}\text { INTERPERSONAL RELATIONS/ } \\
\text { COMMUNICATIONS }\end{array}$ & $\begin{array}{l}8 \\
15 \\
16 \\
17 \\
20 \\
21 \\
22 \\
24 \\
33 \\
34 \\
35 \\
42\end{array}$ & $\begin{array}{l}\text { Promote the inclusion of patient's decisions and desires concerning his care } \\
\text { Communicate a feeling of acceptance of each patient and a concern for the patients } \\
\text { welfare } \\
\text { Seek assistance when necessary } \\
\text { Help a patient communicate with others } \\
\text { Verbally communicate facts, ideas, and feelings to other health team members } \\
\text { Promote patients' rights t privacy } \\
\text { Contribute to an atmosphere of mutual trust, acceptance, and respect among other health } \\
\text { team members } \\
\text { Explain nursing procedures to a patient prior to performing them } \\
\text { Use nursing procedures as opportunities for interaction with patients } \\
\text { Contribute to productive working relationships with other health team members } \\
\text { Help a patient meet his emotional needs } \\
\text { Use opportunities for patient teaching when they arise }\end{array}$ \\
\hline PROFESSIONAL DEVELOPMENT & $\begin{array}{l}43 \\
44 \\
45 \\
46 \\
47 \\
48 \\
49 \\
50 \\
51 \\
52\end{array}$ & $\begin{array}{l}\text { Use learning opportunities for ongoing personal and professional growth } \\
\text { Display self-direction } \\
\text { Accept responsibility for own actions } \\
\text { Assume new responsibilities } \\
\text { Maintain high standards of performance } \\
\text { Demonstrate self-confidence } \\
\text { Display a generally positive attitude } \\
\text { Demonstrate knowledge of the legal boundaries of nursing } \\
\text { Demonstrate knowledge of ethics of nursing } \\
\text { Accept and use constructive criticism }\end{array}$ \\
\hline
\end{tabular}




\section{Results}

The mean age of the first degree graduates was 27.5 with a standard deviation of 5.5. The mean age of the second-degree graduates was 40 with a standard deviation of 9.7. Forty percent of the graduates were working in a medical-surgical department while others worked in pediatrics, intensive care units (ICU), psychiatric units, nursery, informatics, and forensic nursing. Most students (82.2\%) indicated that they planned to return for graduate study in nursing. Fifty percent of both the first degree and second degree graduates want to continue on to higher degrees and certificates.

The self-perceptions of performance according to the six dimension scale questionnaire showed a slightly higher score for the second degree graduates in

clinical practice. The self-perceptions of performance is determined by how frequently an activity is performed and how well the nurses stated they performed the activity (See Table 3). The second degree results of perception of performance suggest they are more comfortable in performing skills such as leadership and professional development roles. There were no significant differences in interpersonal communication skills between the first and second-degree graduates. The results indicated that these accelerated second degree graduates were more likely to perform in and choose roles in leadership as well as roles which would further professional development. This could be due to previous professional capacities and experience in leadership roles. The perceptions of 
first degree graduates were more reflective on communication, planning and evaluating, teaching, and critical care. Overall, both accelerated first degree and second-degree graduates perceive themselves to perform at the same level. There were no significant statistical differences between the two groups in regards to their self-perception of performance. 
Table 3 Independent Samples T-Tests Group Statistics

\begin{tabular}{|c|c|c|c|c|}
\hline & GROUP & $\mathrm{N}$ & Mean & Std. Deviation \\
\hline SCALE 1 LEADERSHIP & $\begin{array}{l}1 \text { FIRST DEGREE } \\
2 \text { SECOND DEGREE }\end{array}$ & $\begin{array}{r}12 \\
8\end{array}$ & $\begin{array}{l}3.275 \\
3.275\end{array}$ & $\begin{array}{l}.4495 \\
.4803\end{array}$ \\
\hline SCALE 2 CRITICAL CARE & $\begin{array}{l}1 \text { FIRST DEGREE } \\
2 \text { SECOND DEGREE }\end{array}$ & 8 & $\begin{array}{l}3.025 \\
2.812\end{array}$ & $\begin{array}{l}.5207 \\
.9125\end{array}$ \\
\hline $\begin{array}{l}\text { SCALE } 3 \text { TEACHING- } \\
\text { COLLABORATION }\end{array}$ & $\begin{array}{l}1 \text { FIRST DEGREE } \\
2 \text { SECOND DEGREE }\end{array}$ & 8 & $\begin{array}{l}3.100 \\
2.950\end{array}$ & $\begin{array}{l}.4612 \\
.6000\end{array}$ \\
\hline $\begin{array}{l}\text { SCALE } 4 \text { PLANNING- } \\
\text { EVALUATION }\end{array}$ & $\begin{array}{l}1 \text { FIRST DEGREE } \\
2 \text { SECOND DEGREE }\end{array}$ & 12 & $\begin{array}{l}3.350 \\
3.150\end{array}$ & $\begin{array}{l}.4503 \\
.6141\end{array}$ \\
\hline $\begin{array}{l}\text { SCALE } 5 \text { IPR- } \\
\text { COMMUNICATIONS }\end{array}$ & $\begin{array}{l}1 \text { FIRST DEGREE } \\
2 \text { SECOND DEGREE }\end{array}$ & 8 & $\begin{array}{l}3.517 \\
3.425\end{array}$ & $\begin{array}{l}.4569 \\
.6135\end{array}$ \\
\hline $\begin{array}{l}\text { SCALE6 PROFESSIONAL } \\
\text { DEVELOPMENT }\end{array}$ & $\begin{array}{l}1 \text { FIRST DEGREE } \\
2 \text { SECOND DEGREE }\end{array}$ & 12 & $\begin{array}{l}3.525 \\
3.575\end{array}$ & $\begin{array}{l}.4555 \\
.4027\end{array}$ \\
\hline
\end{tabular}

\section{Discussion}

Although all the data were self-reported perception of nursing

performance, the results suggest that both groups of accelerated nursing graduates continue to work in acute care settings with appropriate clinical skills. In 
comparing the first degree with the second degree graduates, the results have suggested that although there was no significant differences between the perceptions of performance, first degree accelerated graduates were more comfortable with task oriented situations while second degree graduates are focused in leadership roles. The responses were stated to be performed more frequently and were performed well in most cases. Most of the nurses in the study had been working in a clinical setting from three months to three years.

The first degree nurses perceived that they had been most effectively prepared for professional development, communication, planning, and evaluation. Second degree graduates were found to be more likely to enhance in leadership roles and professional development. This difference may be related to prior experience in other careers. Second degree students have been noted to be desirable by employers because of their maturity, intelligence, and past experiences (AACN, 2005).

Research has shown that $30 \%$ of new graduates leave nursing within the first year due to dissatisfaction with the career, stress and burnout (Bowles \& Candela, 2005). It is important to retain accelerated graduates in the clinical environment since they assist in decreasing the nursing shortage. Accelerated graduates are motivated, self-directed learners who can contribute to the nursing profession and nursing education. 


\section{Limitations}

The major limitation of this study is that data pertaining to performance was self-reported. Future studies are needed to examine staff perceptions and/or nurse leader perceptions of clinical performance of these accelerated graduates in the clinical setting. Another limitation of the study was the small sample size. Only $32 \%$ of the graduates (first and second degree) from a two year graduation cycle responded. Lastly, the study was conducted with graduates of one school in one urban university.

\section{Conclusion}

This study provides evidence that the self-perception of clinical performance of accelerated graduates is high. This agrees with past evidence of research which suggests accelerated students are self-directed and motivated to perform to their best ability (AACN, 2009). Accelerated second degree graduates bring a wealth of knowledge and experience to the nursing profession. Therefore administrators and nurse leaders benefit from having them as employees (AACN, 2006).

Self-perceptions of clinical performance, as well as employer appraisals are pertinent for these self-directed, goal oriented accelerated graduates to remain in acute care nursing facilities. The 52 nursing competencies, which are behaviors 
of nurses in particular situations, were used to assess performance in the clinical setting. The results of this study show that accelerated first and second-degree graduates are confident in performing clinically after graduation. Second degree graduates are more likely to enter professional development and leadership roles while first degree graduates continue to progress in clinical tasks. Although this was a small study, the data provides critical information that could be used for evaluating the performance of future accelerated nursing graduates. The results can help determine if the admission criteria of nursing programs for accelerated students need to change. 


\section{References}

American Association of Colleges of Nursing. (2009). Nursing Shortage. Retrieved June 1, 2009 from http://www.aacn.nche.edu/Media/FactSheets/NursingShortage.htm

American Association of Colleges of Nursing. (2009). Fact Sheet: Accelerated

Baccalaureate and Master's degree in nursing. Retrieved May 25, 2009 from http://www.aacn.nche.edu/Media/FactSheets/AcceleratedProg.htm

American Association of Colleges of Nursing. (2008). Fact Sheet: Accelerated

Baccalaureate and Master's degree in Nursing. Retrieved May 6, 2009 from http://www.aacn.nche.edu/Media/pdf/AccelProgs.pdf

American Association of Colleges of Nursing. (2007). Accelerated baccalaureate and master's degrees in nursing. Retrieved June 13, 2008 from www.aacn.nche.edu/Media/FactSheets/AcceleratedProg.htm

American Association of Colleges of Nursing. (2005). Accelerated programs: The fasttrack to careers in nursing. Retrieved May 18, 2008 from www.aacn.nche.edu/publications/issues/Aug02.htm

American Organization of Nurse Executives (AONE). (2009). The cost of failure. Retrieved May 8, 2009 from http://www.afscme.org/publications/2211.cfm 
Black, L. (2008). Nurses working outside of nursing: Societal trend or workplace crisis? Policy, Politics and nursing practice, 9 (3) 143-157.

Berkow, S., Virkstis, K., Stewart, J., \& Conway, L. (2009). Assessing New Graduate Nurse Performance. Nurse Educator, 34 (1) 17-22.

Bowles, C., \& Candela, L. (2005). First job experiences of recent RN graduates. Journal of Nursing Administration, 35 130-137.

Brewer, C.S., Kovner, C.T., Poornima, S., Fairchild, S., Kim, H., \& Djukic, M. (2009). A comparison of second degree baccalaureate and traditional-baccalaureate new graduate RNs: Implications for the workforce. Journal of Professional Nursing, 25 (1) 5-14.

Bureau of Labor and Statistics (2008). Career guide to industries: Healthcare.

Retrieved January 20, 2009 from http://www.bls.gov/oco/cg/cgs035.htm

Health Resources and Services Administration (HRSA). (2006). Methods for identifying facilities and communities with shortages of nurses, Technical report. Retrieved April 22, 2009 from http://bhpr.hrsa.gov/healthworkforce/nursingshortage/tech report/default.htm

Korvick, L.M., Wisener, L.K., Loftis, L., \& Williamson., M.L. (2008). Comparing the academic performance of students in traditional and second degree baccalaureate programs. Journal of Nursing Education 47 (3) 
McDonald, W.K. (1995). Comparison of performance of students in an accelerated baccalaureate nursing program for college graduates and a traditional nursing program. Journal of Nursing Education, 34, 123-127.

Penprase, B., Koczara, S. (2009). Understanding the Experiences of accelerated seconddegree nursing students and graduates : A review of the literature. The Journal of Continuing Education in Nursing. 40 (2), 74-78

Raines, D.A. (2007). Accelerated second-degree program evaluation at graduation and one year later. Nurse Educator, 32 (4) 183-186.

Raines, D.A. \& Sipes, A. (2007). One year later: Reflections and work activities of accelerated second-degree bachelor of science in nursing graduates. Journal of Professional Nursing, 23 (6) 329-334.

Schwirian, P.M. (1978). Evaluating the performance of nurses: A multi-dimensional approach. Nursing Research, 27 347-351.

Seldomridge, L. A., \& DiBartolo, M.C. (2004). Can success and failure be predicted for baccalaureate graduates on the computerized NCLEX-RN? Journal of Professional Nursing, 20 361-368. 


\section{International Journal of Nursing Education Scholarship}

Thank you for your submission

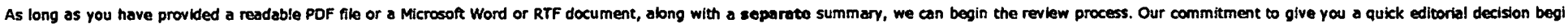

\section{PLEASE VERIFY THAT EVERYTHING IS ACCURATE.}

PDF documents, whether created by the asthor or by the aystem, should be checked, paga by page, for accuracy.

Manuscript Summary

Author

Neelam N. MurthI, Mark C. Crider, and Christine Hooper

Title

Self-Perceptions of Cinical Performance of Accelerated First-Degree and Accelerated Second-Degree Graduates

Keywords

nursing shortage. clinical performance, new graduate. accelerated nursing graduates, first-degree graduates, second-degree graduatse

Subject Area

Accelerated nursing graduates

Type

Article

Abstract

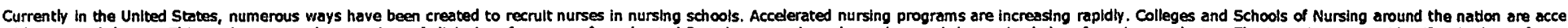

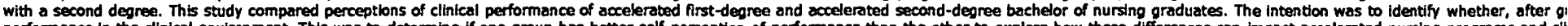

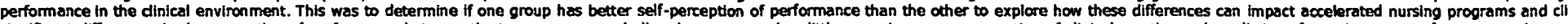

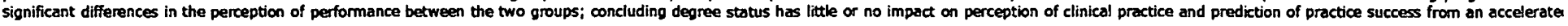

Native File

Nealom DRAFr4_dox 1

PDF File

If the system is creating the PDF file for you, it may take up to 5 minutes for the file to be created.

What's next?

1. You may rendice veur subanisstion 2 now if necessary.

2. Uelend edditionalfike ${ }^{3}$ to be displayed on the web page alongside this manuscript (e.g. data sets, video clips, or sound files).

3. When you have finished, please loa our 4 .

4. You may track the status of your manuscript or submit revisions in the future via your MycAccosunt 5 page.

Pleaso do not subsit o new manuseript as a way to revise this manuseript.

Links

1. http://www.bepress.com/context/jnes/article/1898/type/native/viewcontent

2. hitp://www.bepress.com/cgl/preview.colfarticie =1898\&context=tines

3. hitp://www.bepress.com/cg//uplaad_additional.cgi?articie=18988context=ijnes

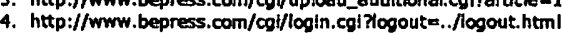

5. hitp://www.bepress.com/cgi/myaccount.cg!

ISS N: $1548-923 X$ 1999-2009 The Berkeley Electronk Press'" All rights reserved.

To submit, subscribe, recommend this joumal to your library, or sign up for email alerts, please visit: http://www. bepress.com/ljnes 